\title{
ICT Initiatives in Educational Examination Management-A Review
}

\author{
Jewan Singh ${ }^{1}$, Vibhakar Mansotra ${ }^{2}$ \\ ${ }^{1}$ Scholar, School of Electrical Engineering, Department of IT, AMET University, India \\ ${ }^{2}$ Professor, Department of Computer Science \& IT, University of Jammu, India
}

\begin{abstract}
In this paper, we present a critical review of the existing research progress on ICT initiative in educational examination management system. The study analyses the research papers published in leading journals, conference proceedings, articles, government web portals, and reports which categorize the existing publications according to type of issues investigated. The review reveal that majority of the papers, articles have examined issues related with limitations of the traditional examination system, examination malpractices, paper leakage, advantages of online examination system, security issues, challenges of integrating ICT in schools, programming tools used to develop online examination system, application of cloud computing in examination management and drawbacks in the existing e-examination system.
\end{abstract}

Keywords: ICT integration challenges, online exams security, e-examination challenges, examination assessment, programming tools.

\section{Introduction}

The advent of web applications into the computing technology has brought about a significant revolution in our social life including the traditional system of education and examination. One important area of application of the technology is in the development of web-based testing and assessment. E-exam management is one of the most important building blocks of an e-learning environment. Eexamination can be defined as a system that "involves the conduct of examinations through the web or the intranet" [1].

\section{Research Methodology}

To examine the technological initiatives in educational examination system, we analyzed existing studies from 19982016. This helps us to set a boundary and enable us to get relevant data. The leading e-government journals, conference proceedings, government's annual reports and survey reports got reviewed.

\section{Review analysis}

The research papers were thoroughly reviewed and the various research issues examined from the existing literature are as under:

\subsection{Review analysis on limitations in the traditional educational examination system}

The most common parameters found under this aspect include; examination malpractices, paper leakage, delay in result declaration, error in grading and marking process, impersonation and wastage of printed resources. The limitations in the traditional educational examination system pointed out by [2],[3],[4],[5,[6] include; examination paper leakage, examination malpractices, low capacity examination venues, impersonation, inadequate invigilators, inadequate examination materials, human error during the marking/grading process, delay in result declaration, wastage of printed resources. The most common factors contributing to school examination paper leakage pointed out by [7] include use of public transport, lack of security, demotivating teaching force, negligence on part of school heads, public pressure for good results, schools ranking and result based rewards, printing and dispatch loopholes and ready market for leaked question papers. In [8] authors pointed out that exams postponed/cancelled due to paper leakage. According to authors in [9] the various factors contributing to examination malpractices includes when a candidate creates disturbance or uses abusive language or uncooperative, display and/or uses electronic communication equipments such as pagers, cellular phones, PDA's, gives or receive help, attempt to record examination questions or make notes, attempt to take examinations for someone else, is observed with notes, books or other aids.

Table 1: List of parameters examined under limitations in the traditional examination system

\begin{tabular}{|c|c|}
\hline Parameters examined & Papers \\
\hline Paper leakage & {$[2],[3],[4],[5],[6],[7],[8]$} \\
\hline Examination malpractices & {$[2],[3],[4],[5],[6],[9]$} \\
\hline Error in marking and grading process & {$[2],[3],[4],[5],[6]$,} \\
\hline Impersonation & {$[2],[3],[4],[5],[6]$,} \\
\hline Delay in result declaration & {$[2],[3],[4],[5],[6]$,} \\
\hline
\end{tabular}

\subsection{Review analysis on advantages of online examination}

The most important parameters found under the advantages of online examination system pointed out by researchers includes; it saves time and cost in managing test and result preparation, reduces fraud and examination malpractices, reduces accommodation problem, auto marking, transparent and scalable, remove human errors recorded in traditional examination system, online availability of questions. In [2] authors pointed out that the integration of examination system bring transparent, scalable, and robust e-governance solutions. According to [9], [10], [11], [12], [13] authors the 


\section{International Journal of Science and Research (IJSR) \\ ISSN (Online): 2319-7064}

Index Copernicus Value (2013): 6.14 | Impact Factor (2015): 6.391

cost prize is reduced in supervision and marking of the answers by adopting of online examination system. In [4], [9] [10], [11] authors examined that online examination system saves time in managing test and getting results. In [1], [14], [15], [16] authors examined that online examination reduces malpractices during examination. In [4], [9], [17], [18], authors pointed out that the challenges of traditional examination will be automatically eliminated following the adoption of e-examination system. In [19] authors developed online examination system that reduces the risk of leakage of examination. In [5], [20] authors proved that online examination system reduces accommodation problem.

Table 2: List of parameters examined under advantages of online examination system

\begin{tabular}{|c|c|}
\hline Parameters examined & Papers \\
\hline $\begin{array}{c}\text { Saves time in managing test and result } \\
\text { preparation }\end{array}$ & {$[4],[9],[10],[11],[12]$.} \\
\hline Cost is reduced & {$[13]$} \\
\hline Reduces malpractices & {$[10],[11],[12],[13]$} \\
\hline $\begin{array}{c}\text { Eliminate challenges of traditional } \\
\text { examination }\end{array}$ & {$[4],[9],[17],[16]$} \\
\hline Reduces paper leakage & {$[18]$} \\
\hline Transparent e-governance solutions & {$[2]$} \\
\hline Reduces accommodation problem & {$[5],[20]$} \\
\hline
\end{tabular}

\subsection{Review analysis on online examination assessment}

Under online examination assessment aspect the most important theme found is an analysis of objective and subjective test.

Table 3: list of issues examined under online examination assessment

\begin{tabular}{|c|c|}
\hline $\begin{array}{c}\text { Examination assessment issues } \\
\text { examined }\end{array}$ & Papers \\
\hline Objective questions assessment & {$[21],[22],[23],[24]$} \\
\hline Subjective questions assessment & {$[16],[24],[25],[26],[27]$,} \\
& {$[28],[29],[30]$} \\
\hline
\end{tabular}

In [21], [22], [23], [24] authors developed an online examination system which carries out the examination and auto-grading for objective questions. In [16], [24], [25], [26], [27], [28], [29], [30] authors developed subjective examination assessment system that is able to access subjective question answers.

\subsection{Review analysis on online examination security}

Under online examination security aspect the most important parameters found in papers include; username and password authentication schemes, cryptographic schemes, integrity and monitoring schemes, biometric authentication schemes, IP camera based monitoring, security vulnerabilities. In [21], [31], [38] authors are of the view that security issues in examination can be managed by adopting username and password schemes and IP camera based monitoring. In [6], [16], [32], [33], [34], [35], [36] authors are of the view that security issues in online examination system can be managed by adopting cryptographic schemes. According to [6], [36], [37], [38], [39], [40], [41], [42] authors the security issues in online examination system can be managed by adopting biometric authentication schemes. In [36], [43] authors elaborated that online examination security can be maintained by using internet firewall concept.

Table 4: List of parameters examined under examination security management

\begin{tabular}{|c|c|}
\hline Security issues examined & papers \\
\hline $\begin{array}{c}\text { Username and password authentication } \\
\text { scheme and Web Camera based } \\
\text { monitoring }\end{array}$ & {$[21],[31],[38]$} \\
\hline $\begin{array}{c}\text { Cryptographic schemes for security } \\
\text { management }\end{array}$ & {$[6],[16],[32],[33]$,} \\
{$[34],[35],[36]$} \\
\hline Biometric authentication schemes & {$[6],[36],[37],[38]$,} \\
& {$[39],[40],[41],[42]$} \\
\hline Internet Firewall & {$[36],[43]$} \\
\hline
\end{tabular}

\subsection{Review analysis on programming tools used in developing online examination system}

The various technologies used by the researchers to develop online examination system includes; Java, C\#, Microsoft visual studio, Python, Perl, ASP.Net, HTML, PHP, MYSQL, SQL Server and MS Access.

Table 5: Programming tools used to develop online examination management system

\begin{tabular}{|c|c|}
\hline Programming tools used & Papers \\
\hline Microsoft Visual Studio & {$[4],[41]$} \\
\hline Microsoft SQL Server & {$[4],[44]$} \\
\hline Java and Net beans & {$[5],[20]$} \\
\hline MYSQL & {$[5],[12],[19],[22]$} \\
\hline PHP & {$[12],[19],[22],[45]$} \\
\hline MS Access & {$[20]$} \\
\hline Python with NLTK tool kit & {$[27]$} \\
\hline C\# with Microsoft Visual Studio & {$[41],[44]$} \\
\hline ASP.Net & {$[44]$} \\
\hline HTML & {$[4],[22],[44]$,} \\
\hline Perl & {$[45]$} \\
\hline
\end{tabular}

In [4] authors developed computer-based test system using HTML, Microsoft Visual Studio 2012 and Microsoft SQL Server 2008. In [5] authors developed computer based examination system by using Java Servlet, Net Beans IDE 7.2 as front-end development tools and MYSQL as back end tool. In [12] authors developed result processing system using PHP and MYSQL. In [19] authors used different tools to develop the online examination system which includes XHTML, CSS, Photoshop, Micro media Dream Waiver, Micro media Fireworks, PHP, MYSQL, Apache Server, and Symfony 1.4 framework. In [20] authors developed computerized examination system by using Java as front end tool, Net Beans 8.0 as IDE and MS Access as back end tool. In [22] authors developed an online examination system using various open source technologies such as AJAX, PHP, HTML and MYSQL database engine. In [27] authors developed subjective examination assessment system that was built using Python with NLTK tool kit. In [41] authors developed online examination in Microsoft C\# programming language using Microsoft visual studio framework. In [44] authors developed online examination application using ASP.NET web server, $\mathrm{C \#}$ as the intermediate language, ADO.NET to interact with the relational database and Microsoft SQL server as the relational database. In [45] 


\section{International Journal of Science and Research (IJSR) \\ ISSN (Online): 2319-7064}

Index Copernicus Value (2013): 6.14 | Impact Factor (2015): 6.391

authors developed computer proficiency skill test using Macromedia flash, HTML, JavaScript, PHP script and Perl script.

\subsection{Review analysis on challenges in adopting online examination in educational institutions}

The major parameters found under this aspect include; lack of IT infrastructure to house technology, teachers refusing to learn new technology, complexities in software usage, security issues, misuse of ICTs by students, inadequate electricity, computer illiteracy, technical barrier, funds management issues, lack of internet connectivity.

Table 6: List of challenges pointed out by the researchers in adopting online examination system

\begin{tabular}{|c|c|}
\hline Challenges pointed out & Papers \\
\hline Lack of ICT infrastructure & {$[2],[6],[18],[46]$,} \\
& $\begin{array}{c}{[47],[48],[50],[51],} \\
{[53]}\end{array}$ \\
\hline Lack of technology Knowledge and skills & $\begin{array}{c}{[15],[18],[46],[47],} \\
{[48],[50],[51]}\end{array}$ \\
\hline Lack of User friendly interface & {$[6],[15],[46],[47]$} \\
\hline Resistance of teachers to use technology & {$[2],[46],[47],[48]$} \\
\hline Lack of sufficient number of Computers & {$[6],[53]$} \\
\hline Lack of internet & {$[50],[51],[53]$} \\
\hline Lack of Security & {$[15],[52]$} \\
\hline Misuse of Technology & {$[48]$} \\
\hline Technical barrier & {$[49],[53]$} \\
\hline Institutional barrier & {$[46],[47],[49]$} \\
\hline Different computing platform & {$[45]$} \\
\hline Change examination process & {$[53]$} \\
\hline
\end{tabular}

According to authors in [2], [6], [18], [46], [47], [48], [50], [51], [53] the key challenge in adopting online examination system in educational institutions include; lack of ICT infrastructure to house technology. In [15], [18], [46], [47], [48], [50], [51] authors are of the view that the key challenge in adopting online examination system in educational institutions include lack of computer usage and operating skills. Studies in [6], [15], [46], [47] revealed that many of the online examination system have not user friendly interface. Studies in [2], [46], [47], [48] found that the key challenge in adopting online examination system is the resistance of teachers to use technology. In [6], [53] authors pointed out in their work that there are not sufficient computers in the educational institutions to adopt online examination system. Studies in [50], [51], [53] revealed that non availability of internet facility affects the acceptance of online examination system. In [15], [52] authors elaborated that lack of data security affects the acceptance of online examination system. Studies in [48] revealed that students misuse the ICTs which hamper the exploration and exploitation of ICT opportunities. According to authors in [49], [53] technical failure and malfunctioning of hardware components on the day of examination affects the acceptance of online examination system. Studies in [46], [47], [49] elaborated that lack of institutional polices and procedure to adopt online examination affects the acceptance of online examination. In [45] authors pointed out in their work that different computing platform affects the acceptance of online examination system. In [53] authors elaborated that implementation of computer-based examinations lead to significant changes in almost all aspects of examination processes (change academic culture, change management task, organizational changes, reorganization of examination processes, admission processes) that affects the acceptance of online examination system.

\subsection{Review analysis on application of cloud computing in e-examination management}

The advantages of using cloud computing in online examination management include; optimum utilization of existing infrastructure, cost reduction, reduces effort in managing technology, powerful computing and storage capacity, virtualization, resource pooling, rapid deployment and reusability, maintainability and scalability.

Table 7: Cloud computing benefits in examination management

\begin{tabular}{|c|c|}
\hline Cloud computing benefits & Papers \\
\hline $\begin{array}{c}\text { Reduces cost and time to build } \\
\text { infrastructure }\end{array}$ & {$[54],[55],[59],[62]$} \\
\hline Power computing and storage capacity & {$[58],[62]$} \\
\hline Virtualization & {$[58],[61],[62]$} \\
\hline Reduce technical failure risk & {$[54],[55],[62]$} \\
\hline anywhere accessibility & {$[54],[55],[58],[62]$} \\
\hline Easier to maintain and upgrade & {$[54],[55],[59],[62]$} \\
\hline $\begin{array}{c}\text { Solve different computing platform } \\
\text { complexity }\end{array}$ & {$[54],[55],[59],[62]$} \\
\hline Solve management issues & {$[54],[55],[62]$} \\
\hline Reduces resistance to change & {$[54],[55]$} \\
\hline Handling system loads & {$[57]$} \\
\hline $\begin{array}{c}\text { Application of cloud computing in online } \\
\text { examination management }\end{array}$ & {$[56],[57],[60],[62]$} \\
\hline
\end{tabular}

According to authors in [54], [55] [59], [62] cloud computing offer some potential solutions to overcome many of challenges which include; reduces the cost and time needed to build the infrastructure. In [58], [62] authors described that the cloud computing provide powerful computing power and huge data storage space. In [58], [61], [62] authors identified that cloud computing provide virtualized access to data. In [54], [55], [62] authors described that cloud computing reduces technical failure risk. In [54], [55], [58], [62] authors described that cloud computing offer anywhere accessibility. According to authors in [54], [55], [59], [62] cloud computing environment are easier to maintain and upgrade. In [54], [55], [59], [62] authors pointed out that cloud computing solve different computing platform complexities. In [54], [55], [62] authors described that cloud computing solve the problem of management. In [57] authors pointed out that cloud computing handle varying system loads. Authors in [56], [57], [60], [62] proposed and designed online examination system using cloud computing and also focused on the application of cloud computing in managing examination system.

\subsection{Review analysis on the drawbacks in the existing e- examination system}

Over the years, there have been various automated examination systems that have been developed with one or more limitation.

\section{Volume 5 Issue 6, June 2016}




\section{International Journal of Science and Research (IJSR) \\ ISSN (Online): 2319-7064}

Index Copernicus Value (2013): 6.14 | Impact Factor (2015): 6.391

Table 8: List of drawbacks pointed out by the researchers in the existing online examination system

\begin{tabular}{|c|c|}
\hline Limitations acknowledged & Papers \\
\hline Result integrity & {$[4],[49],[64],[67]$} \\
\hline Lack of security & {$[5],[19],[67]$} \\
\hline Lack of control & {$[24]$} \\
\hline $\begin{array}{c}\text { More investment needed in the area of } \\
\text { ICT infrastructure development }\end{array}$ & {$[65]$} \\
\hline Computer crashes occur & {$[65]$} \\
\hline Question paper repetition & {$[65]$} \\
\hline Paper setting and scripting are tedious & {$[49]$} \\
\hline Lack of robustness and flexibility & {$[4],[64]$} \\
\hline Unauthorized access & {$[66]$} \\
\hline
\end{tabular}

In [4], [49], [64], [67] authors observed that result integrity is the major limitation acknowledged in the existing online examination system. In [5],[19],[67] Authors found that ensuring security of the online question still remains a challenge. In [24] authors mentioned in their work that computers used by students to write the exams are not under the control of examination conducting authorities. In [65] authors pointed out that more investment is needed in the area of infrastructure and human development, computer crashes occur, question bank needs to be large enough to prevent question repetition. In 49 authors found that paper setting, scripting are very tedious in online examination system. In [4], [64] authors found that existing online examination system lacks flexibility, robustness and scalability. In [66] authors found that in online examination system a candidate can easily use of any unauthorized methods and can enjoy outer guidance to score good in the examination.

\section{Findings}

The ICT initiatives in educational examination system are explored in this study. A literature review was carried out in which we reviewed relevant papers for the period 19982016. Based on this review following findings are drawn;

- The most common limitations found in the traditional examination system include examination malpractices, low capacity examination venues, inadequate invigilators, inadequate examination materials, and human error during the marking/grading process. [Table 1].

- The various factors responsible for examination paper leakage identified by researchers include use of public transport, lack of security, de-motivating teaching force, negligence on part of school heads, public pressure for good results, schools ranking and result based rewards, printing and dispatch loopholes, ready market for leaked question papers. [Table 1].

- The various factors contributing to examination malpractices experienced worldwide include paper leakage, external assistance, smuggling of unfair materials , involvement of invigilators, writing answer on the blackboard, circulating sheets of work during course of examination, involvement of candidates, friends, teachers, candidate create disturbance or abusive or uncooperative, display and/or uses electronic communication equipment such as pagers, cellular phones, PDA's, gives or receive help, attempt to record examination questions or make notes, attempt to take examinations for someone else, is observed with notes, books or other aids.[Table 1].

- The advantages of online examination system pointed out by different authors include cost prize is reduced in supervision and marking of the answers, time saving, reduces turnaround, reduces resources needed by replacing human resources with computer resources, few people are required to supervise the examination, results available instantly. [Table 2].

- The e-marking systems developed by different authors are able to evaluate the objective as well as subjective question papers. [Table 3].

- The security of online examination system can be achieved by utilizing technologies such as biometric authentication, internet firewall, cryptography, Network protocol, digital signature, web Cam, Finger print scanner. [Table 4].

- The programming tools used by different researchers to develop the online examination system include HTML, Microsoft visual studio, ADO.NET, C\#, Python, Java, ASP.NET, Microsoft Access, Microsoft SQL. [Table 5].

- The various challenges identified by authors in the literature to integrate the ICT in examination management include; lack of IT infrastructure, inadequate electricity, computer illiteracy, lack of internet facility, lack of resources, lack of technology knowledge and skills, refusing to learn new technology, misuse of ICT by students, teachers need to trained, lack of motivational quality, frequent changes in administration, institutional barriers, attitudes and beliefs towards technology, lack of integrating technology in assessment process, lack of integrating technology in subject culture. [Table 6].

- The application of using cloud computing reduces hardware and maintenance cost, provide the accessibility around the globe, flexibility and highly automated processes wherein the customer need not worry about concerns like software up-gradation and load balancing. [Table 7].

- The drawbacks reported by researchers in the existing online examination system include; result integrity, lack of flexibility, robustness and scalability, lack of timing functionality to automatically log-off candidates upon expiration of allotted time, Lack of secure e-examination, in case of system crash exams will not be conducted, server problem can bring the system to halt, subjective questions are not evaluated, difficulty in drawing diagram in the existing online examination system. [Table 8].

\section{Conclusions}

Over the year there has been incremental growth in computer-based testing as a viable alternative to paper -and -pencil testing. Even though online examinations are on their boom, still there exist some cons which need to be brushed.

\section{Future Scope}

There could be possibility that some papers might have been equally useful have been missed. There remains much room for in depth analysis of the ICT initiatives in educational examination management. 


\section{International Journal of Science and Research (IJSR) \\ ISSN (Online): 2319-7064}

Index Copernicus Value (2013): 6.14 | Impact Factor (2015): 6.391

\section{References}

[1] C. K. Ayo, I. O. Akinyemi, A. A. Adebiyi, U. O. Ekong, "The Prospects of e-examination implementation in Nigeria", Turkish Online Journal of Distance Education, 8(4), pp. 125-134, 2007.

[2] M. Bhardwaj, A. J. Singh, "E-Governance: Single portal for integrated Examination System," Emerging Technology in E-Government, pp.288-293, 2008.

[3] Y.S Chouhan, N. Jaiswal, "Cogitation and Analysis of e-exam Model for Autonomous College", International Journal of Emerging Technology and Advanced Engineering, 3(12), pp.287-290, 2013.

[4] Fagbola Temitayo M., Adigun Adebisi A., Ohe Alice O., "Computer-Based Test (Cbt) System for University Academic Enterprise Examination", International Journal of scientific and technology research, 2(8), pp.336-342, 2013.

[5] Archana M., Leelavathi R., "An Effective Computer Based Examination System for University", International Journal of Science and Research (IJSR),4(2),pp.539-542,2015.

[6] O. Adebayo, S. M. Abdulhamid, "E-Exams System for Nigerian Universities with Emphasis on Security and Result Integrity," International Journal of the Computer, the internet and Management, 18(2), pp.47.1-47.12.

[7] Mashanyare Isao, Chinamasa Emmanuel, "School examination Leakage: Case of Zimbabwe School examinations council", IOSR Journal of Humanities and Social sciences, 19 (4), pp. 47-54, 2014.

[8] Sri Harsha N., Raghavendra Shetty and Prathap. N.L, "Electronic Protection to exam paper leakage", International journal of Engineering Research and Technology, 2(5), pp. 1105-1111, 2013.

[9] Rout Ghanashyam and Patnaik Srikanta, "A case study on E-Examination in Universities of Odisha" International Journal of Internet Computing, I(2), pp.12-20, 2011.

[10] McCormac C., Jones D., Building a Web-based Education System, Wiley Computer Publishing New York, USA, 1998.

[11] Ryan S., Scott B., Freeman F., Patel D., "The Virtual University, The Internet and Resource-Based Learning”, Kogan Page, London, 2000.

[12] Ezenma A. Anulika, Emmanuel Bala , Choji D. Nyap, "Design and Implementation of Result Processing System for Public Secondary Schools in Nigeria", International Journal of Computer and Information Technology,03(01),pp.121-127, 2014.

[13] T.Rama Thulasi, M.Vinodh Kumar, M.Dinesh, "Mobile Examination System", "International Journal of Computer Science and Engineering", 2(4),pp. 64-69, 2015.

[14] F. Andrew, Darren Pullen, Colleen Harper, "Case study of a computer based examination system", Australian Journal of Educational Technology, 25(4), pp.509- 523, 2009.

[15] M.V. Okonkwo, C. Akuadi, "Adapting on demand examination system in national open university of Nigeria end of semester examination," Turkish Online
Journal of Distance Education, 12(4), pp.167-178, 2011.

[16] Namrata Parekh, Kalpesh Dusane,Shivam Thakur, Amoli Sonawane, "Virtual Subjective Examination on Tablets", International Journal of Computer Science and Information Technologies,6 (5), pp. 46894691,2015.

[17] Awosiyan Kunle, "Stress and success of NOUN examination", Nigerian Tribune, p. 10,2010.

[18] Adegbija, M.A. Fakomogbon, F. O. Daramola, "The New Technologies and the conduct of E-Examinations: A Case Study of National Open University of Nigeria," British Journal of Sciences, 3(1), pp.59-66, 2012.

[19] Islam M. Z., Rahman, M. M.,Islam M. K., "Online Examination System in Bangladesh Context", International Journal of Science, and Technology 2(3), pp.351 - 359, 2013.

[20] Leelavathi R., Archana M., "A Novel Computerized Examination System", International Journal of Engineering Trends and Technology (IJETT), 20(1), pp.17-20, 2015.

[21] Zhenming Y. Y., Z. Liang, Z. Guohua, “A Novel WebBased Online examination System for Computer Science Education", $33^{\text {rd }}$ ASEE/IEEE Frontiers in education conference, S3F-7-S3F-10, 2003.

[22] Rashad, M. Z., M. S. Kandil, A. E. Hussan, M. A. Zaher, "An Arabic Web-Based Exam Management System", International Journal of Electrical and Computer Sciences, 10 (01)pp. 48-55, 2010.

[23] Wojciech Bieniecki, Jacek Stando, Sebastian Stolinski, "Information Technologies in a process of Examination in Poland", www.google.com.

[24] Annand David and Huber Collean, "Development of an Automated Exam Marking System at Athabasca University" www.google.com.

[25] Jang Minsu, Joo-Chan Sohn, Hyun Kyu Cho, "Automated Question Answering using Semantic Web Services”, IEEE Asia-Pacific Services Computing Conference, 2007.

[26] Dhokrat Asmita, Gite Hanumant R, C. Namrata Mahender, "Automated answering for Subjective Examination", International Journal of Computer Application, 56(14), pp.14-17, 2012.

[27] Dhokrat Asmita, Gite Hanumant R and C. Namrata Mahender, "Assessment of Answers: Online Subjective Examination", Proceeding of the workshop on Questions Answering for complex domains, Mumbai, pp.47-56, 2012.

[28] Mr. Shinde A. A., Ms. Chokhandre Sumedha, "A Novel Approach with Subjective Assessment For EExamination", International Journal of Engineering Research and Application, 3 (4), pp. 32-36, 2013.

[29] Trivedi Arpit, Mahida Shreya, "Implementation of Bayesian Theory in Sentence Classification for Online Subjective Test", International Journal of Advanced Research in Computer Science and Software Engineering,3(12), pp.439-442, 2013.

[30] Praveen Sheeva, "An approach to evaluate subjective questions for online Examination System", International journal of Innovative Research in Computer and Communication Engineering, 2(11), pp.6410-64-13, 2014.

\section{Volume 5 Issue 6, June 2016 www.ijsr.net}




\section{International Journal of Science and Research (IJSR) \\ ISSN (Online): 2319-7064}

Index Copernicus Value (2013): 6.14 | Impact Factor (2015): 6.391

[31] M. Chaitanya Suman, K.Prathyusha, "Wireless Camera based Online Examination Security", International Journal of Engineering Research and Applications, 2(2), pp.1432-1435, 2012.

[32] J.C Adams, A.A. Armstrong, "A web based testing", World Wide Web.Vol.52(3), pp.193-208, 1998.

[33] C. Rogers, "Faculty perceptions about e-cheating during online chating”, J. Comput. Sci.Colleges, 22(2), pp.206-212, 2006.

[34] Jordi Castella-Roca, Jordi Herrera-Joancomarti and Aleix Dorca-Josa, "A Secure E-Exam Management System", In proceedings of the First International Conference on Availability, Reliability and Security IEEE Computer Society, 2006.

[35] Andrea Huszti, Attila Petho, "A secure electronic exam system”, Publ. Math, Debrecen, 77(3-4), pp.299-312, 2010.

[36] Sarrayrih Mohammad A, IIyas Mohammed, "Challenges of Online Exam, Performance and problems for Online University Exam”, International Journal of Computer Science Issues, 10(1), pp.439443, 2013.

[37] Gordon M., Sankaranarayanan S., "Biometric security mechanism in Mobile payments", In Wireless And Optical Communications Networks (WOCN), 2010 Seventh International Conference IEEE, pp. 1-6, 2010.

[38] Sabbah, Yousef, Imane Saroit, Amira Kotb, "An Interactive and Secure E-Examination Unit (ISEEU)-A proposed model for Proctoring Online Exams" Roedunet International Conference (C) IEEE Xplore, pp.1-5, 2011.

[39] V Wang, S., Liu, J., "Biometrics on Mobile Phone", Recent Applications in Biometrics, 4 (9), pp.38853887.

[40] Tresadern P. A., McCool C., Poh N., Matejka P., Hadid A., Levy C., Marcel S., "Mobile biometrics (mobio): Joint face and voice verification for a mobile platform”, IEEE Pervasive Computing, 99, 2012.

[41] Madhu Babu Anumolu, N.Bharadwaj, "An Online Examination System Using Wireless Security Application",International Journal of Engineering Trends and Technology, 2013.

[42] Al-Ani M. S., Al_Baset K. A., "Efficient Watermarking based an Robust Biometric Features", In IRACST - Engineering, Science and Technology: An International Journal, 3(3), pp. 529-534, 2013.

[43] N.Sendhil Kumar, Agarapu Raghavendra, "Secure Online Examination Management System Using Firewall Setting", SSRG International Journal of Computer Science and Engineering (SSRG-IJCSE), 2(5), pp.185-191, 2015.

[44] O. A. Akinsanmi, O.T. Ruth, M.B. Soroyewun, "Development of an E-Assessment Platform for Nigerian Universities", Research Journal Applied Sciences, Engineering and Technology, 2(2), pp. 170$175,2010$.

[45] Nancy Kinnersley, Scott Mayhew, H. Scott Hinton, "The design of a web-based computer proficiency examination", 31st ASEE/IEEE Frontiers in Education Conference. Session F2C:F2C3-F2C7, 2001.
[46] M. Kuikka, M. Kitola, M-J. Laakso, "Challenges when introducing electronic exam," Research in Learning technology, 22, pp.1-10, 2014.

[47] K. F. Hew, T. Brush, "Integrating technology into K-12 teaching and learning: current knowledge gaps and recommendations for future research," Education Tech Research Dev (Springer), 2007.

[48] P. Samaya, C. Jose, V. Iyengar, N. Ghag, "The Pros and Cons of Integrating ICT in an Educational Institution," In Proceedings of the 6th National Conference INDIACom, 2012.

[49] J. Attewell, "Mobile technologies and learning," www.lsda.org.uk/files/PDF/041923RS.pdf. Federal Ministry of Education (2004). Ministerial initiative on e- examination for Nigerian education system. $e$ Education Project.

[50] Department of School Education \& Literacy, MHRD, Government of India, "Implementations in Government Schools-India," National Institute of Smart Governance report, India.

[51] V. Sharma, V. Mansotra, G.S. Sambyal, "Digital divide in Education-A concern for J\&K state," In Proceedings of the 3rd National Conference INDIACom -2009, pp.73-78, 2009.

[52] K. M. Apampa, G. Wills, D. Argles, " User security issues in summative e-assessment security," International Journal of Digital Society, 1( 2), 2010.

[53] Dr. Yvonne Bauer, Dr. Lars Degenhardt, Dr. Harald Gilch, Dr. Bernd Kleimann, Dr. Klaus Wannemacher, "Online Exams as Part of the IT-supported Examination Process Chain".

[54] B. Dong, Q. Zheng, J. Yang, H. Li, M. Qiao, “An Elearning Ecosystem Based on Cloud Computing Infrastructure," In Proceedings of the Ninth IEEE International Conference on Advanced Learning Technologies 2009, pp.125-12, 2009.

[55] E. Aljenaa, F. Al-Anzi, M. Alshayeji, "Towards an efficient e-learning system based on cloud computing," In Proceedings of the Second Kuwait Conference on eServices and e-Systems 2011, ACM.

[56] T. Prasad, A. Acharya, "An Architecture of Cloud Computing Based Online Examination System," International Journal of Computer Science and Technology, 3(2), pp.524-526, 2012.

[57] P.Govind Raj, Pradeep Kumar, Soumya Sengupta, Kartikeye Vats, P. R. Gupta "An Architectural Insight into the National Online Examination System", International Journal of e-Education, e-Business, eManagement and e-Learning, 2 (2),pp.126-131, 2012.

[58] Md. A. H. Masud, X. Huang, "An E-learning System Architecture based on Cloud Computing," International Journal of Computer, Electrical, Automation, Control and Information Engineering, 6(2), pp. 255-259, 2012.

[59] F. Karim, R. Goodwin, "Using Cloud Computing in Elearning Systems," International Journal of Advanced Research in Computer Science \& Technology, 1(1), pp. 65-69, 2013.

[60] P. Deshpande, P. Sonone, G. Patil, A. Achari, "Online Virtual Subjective Examination System Based Under Ubiquitous Cloud," International Journal of Science and Research, 4(1), pp. 526-529, 2015. 
[61] K. A. Shakil, S. Sethi, M. Alam, "An Effective Framework for Managing University Data Using a Cloud Based Environment," In Proceddings of 9th National Conference INDIACom, pp. 8.60-8.65, 2015.

[62] Jewan Singh, Vibhakar Mansotra, "A Cloud based Solution for Online Examination Management in Education-An Architecture", International Journal of Science and Research, 5(4), pp.1922-1928, 2016.

[63] B.Ipaye, "E-learning in a Nigerian open University",National Open University of Nigeria, pp. 1-11,2009.

[64] Osang Francis, "Electronic Examination in Nigeria, Academic Staff Perspective-Case Study: National Open University of Nigeria (NOUN)", International Journal of Information and Education Technology, 2(4), pp 304-307, 2012.

[65] Aakash Trivedi, "A relevant online examination system", t4E 2010.

[66] Y. Levy, M.M. Ramim , "A Theoretical Approach for Biometrics Authentication of e- Exams", Nova Southeastern University, USA, pp. 93-101, 2007.

\section{Author Profile}

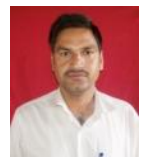

Jewan Singh is presently working as Lecturer in Computer Science in the School Education department Jammu and Kashmir state Government, India and completed MCA from Kurukshetra University, Kurukshetra, India in 2004 and pursing $\mathrm{Ph}$. D. from School of Electrical Engineering, Department of IT, AMET University, Tamilnadu, India. He has more than 14 years experience in teaching. He published and presented research papers in national, international conferences and journals. His research interests are in the field of, E-Governance, ICT, Education Technology, e-learning and Cloud computing.

Prof. Vibhakar Mansotra is presently working as Professor, Department of Computer Science \& IT, University of Jammu, J\&K, India. He received his Ph. D. from University of Jammu, Jammu, India. He has more than 25 years of experience in teaching. He has published, reviewed and presented many research papers in national and international conferences and journals. His current interest includes cloud computing, data mining, information retrieval and e-Governance. 